\title{
Review Article \\ Research Progress on Chemical Constituents of Zingiber officinale Roscoe
}

\author{
Yan Liu $\left(\mathbb{D},{ }^{1}\right.$ Jincheng Liu, ${ }^{2}$ and Yongqing Zhang $\mathbb{D}^{1}$ \\ ${ }^{1}$ School of Pharmacy, Shandong University of Traditional Chinese Medicine, Jinan 250355, China \\ ${ }^{2}$ School of Chemical and Chemical Engineering, Shandong University of Technology, Zibo 255049, China \\ Correspondence should be addressed to Yongqing Zhang; zyq622003@126.com
}

Received 19 August 2019; Revised 4 November 2019; Accepted 26 November 2019; Published 21 December 2019

Academic Editor: Guiming Liu

Copyright (C) 2019 Yan Liu et al. This is an open access article distributed under the Creative Commons Attribution License, which permits unrestricted use, distribution, and reproduction in any medium, provided the original work is properly cited.

Zingiber officinale Roscoe is commonly used in food and pharmaceutical products but can also be used in cosmetics and daily necessities. In recent years, many scholars have studied the chemical composition of Zingiber officinale Roscoe; therefore, it is necessary to comprehensively summarize the chemical composition of Zingiber officinale Roscoe in one article. The purpose of this paper is to provide a comprehensive review of the chemical constituents of Zingiber officinale Roscoe. The results show that Zingiber officinale Roscoe contains 194 types of volatile oils, 85 types of gingerol, and 28 types of diarylheptanoid compounds, which can lay a foundation for further applications of Zingiber officinale Roscoe.

\section{Introduction}

Zingiber officinale Roscoe (ZOR, also Shengjiang in Chinese) is a perennial herb from the Zingiberaceae family, native to the Pacific Islands. It can be found in the Chinese provinces of Shandong, Henan, Hubei, Yunnan, Guangdong, Sichuan, and Jiangsu. ZOR is the fresh root of ginger, which is not only an important condiment but also one of the most commonly used Chinese medicines in clinical practice. Traditional Chinese medicine believes that ZOR has effects of releasing exterior and dissipating cold, arresting vomiting, resolving phlegm, and relieving coughs and can be used to treat fish and crab poison, stomach colds and vomiting, and cold sputum cough [1]. Modern pharmacological studies have shown that ZOR can promote digestion, improve blood circulation, lower blood lipids, lower blood sugar, relieve vestibular stimulation, and provide anti-inflammatory, antitumor, antimicrobial, and antioxidant effects [2-5]. Due to its rich active constituents, ZOR has been used in cosmetics [6], toothpaste [7], and health foods [8-10].

All development and utilization of ZOR are based on its material composition. The chemical composition of ZOR is complex, includes more than 300 types of species, and can be broadly divided into three categories: volatile oils, gingerol, and diarylheptanoids [11-13]. In this paper, the existing research literature of ZOR is systematically summarized, and each chemical composition and its chemical structure are listed in detail, with a view to providing references for quality control, cultivation production, and further development of ZOR.

\section{Constituents}

2.1. Volatile Oils. Volatile oils, also known as ginger essential oils, are generally composed of terpenoids [14]. Ginger essential oils give ZOR a unique aromatic smell [11]. The volatile oil composition varies based on where the $\mathrm{ZOR}$ is harvested. Currently, the ingredients identified in the volatile oils of ZOR and their chemical structures are shown in Table 1.

2.2. Gingerol. Gingerol is the spicy component of ZOR. It is a mixture of various substances, all of which contain the 3methoxy-4-hydroxyphenyl functional group. Gingerols can be divided into gingerols, shogaols, paradols, zingerones, gingerdiones, and gingerdiols, according to the different fatty chains connected by this functional group $[28,29]$. The structural formulas are given in Table 2. 
TABle 1: Volatile oils in ZOR.

\begin{tabular}{|c|c|c|c|c|}
\hline No. & Type & Name & Structure & Reference \\
\hline 1 & Terpene & $\alpha$-Terpinene & & {$[15]$} \\
\hline 2 & Terpene & $\alpha$-Terpineol & & {$[15]$} \\
\hline 3 & Terpene & 4-Terpineol & & {$[15]$} \\
\hline 4 & Terpene & Terpinolene & & {$[15]$} \\
\hline 5 & Terpene & $\gamma$-Terpinolene & & {$[15]$} \\
\hline 6 & Alcohol & Cineole & & {$[15]$} \\
\hline 7 & Alcohol & $\beta$-Eudesmol & & [15] \\
\hline 8 & Alcohol & Nerol & & [15] \\
\hline 9 & Alcohol & trans-Nerolidol & & {$[15]$} \\
\hline 10 & Alcohol & 4-Isopropylbenzyl alcohol & & {$[15]$} \\
\hline 11 & Alcohol & 3,7-Dimethylocta-1,6-dien-3-ol & & {$[15]$} \\
\hline 12 & Alcohol & 3,7-Dimethyloct-6-en-1-yn-3-ol & & [15] \\
\hline 13 & Alcohol & 3-Methylhexan-2-ol & & {$[15]$} \\
\hline 14 & Alcohol & cis-Piperitol & & {$[15]$} \\
\hline
\end{tabular}


TABle 1: Continued.

\begin{tabular}{|c|c|c|c|c|}
\hline No. & Type & Name & Structure & Reference \\
\hline 15 & Alcohol & Borneol & & {$[15]$} \\
\hline 16 & Alcohol & Elemol & & {$[15]$} \\
\hline 17 & Alcohol & tau-Muurolol & & {$[15]$} \\
\hline 18 & Alcohol & 2-Methoxy-1,7,7-trimethylbicyclo[2.2.1]heptane & & {$[15]$} \\
\hline 19 & Alcohol & 1-Isopropyl-4-methylcyclohex-3-enol & & {$[15]$} \\
\hline 20 & Alcohol & 2-Tetradecanol & & [15] \\
\hline 21 & Alcohol & Myrtenol & & {$[15]$} \\
\hline 22 & Alcohol & Citronellol & & {$[15]$} \\
\hline 23 & Alcohol & Geraniol & & [15] \\
\hline 24 & Alcohol & cis-Linalool oxide & & [15] \\
\hline 25 & Alcohol & 4-Ethoxybutan-1-ol & & [15] \\
\hline 26 & Alcohol & $\alpha$-Eudesmol & & [15] \\
\hline 27 & Alcohol & Nerolidol & & [15] \\
\hline 28 & Alcohol & Farnesol & & {$[15]$} \\
\hline 29 & Alcohol & trans-4-Isopropyl-1-methyl-2-cyclohexen-1-ol & & [15] \\
\hline
\end{tabular}


TABLE 1: Continued.

\begin{tabular}{|c|c|c|c|c|}
\hline No. & Type & Name & Structure & Reference \\
\hline 30 & Alcohol & cis-4-Isopropyl-1-methyl-2-cyclohexen-1-ol & & {$[15]$} \\
\hline 31 & Alcohol & 2-Heptanol & & {$[16]$} \\
\hline 32 & Alcohol & 1-Methoxy-2-methyl & & {$[16]$} \\
\hline 33 & Alcohol & cis-Sesquisabinene hydrate & & {$[17]$} \\
\hline 34 & Alcohol & cis-2-p-Menthen-1-ol & & [17] \\
\hline 35 & Alcohol & endo-Borneol & & {$[17]$} \\
\hline 36 & Alcohol & trans-Sabinene hydrate & & [17] \\
\hline 37 & Alcohol & 2-Nonanol & & [18] \\
\hline 38 & Alcohol & Propanol & & [18] \\
\hline 39 & Alcohol & cis- $\beta$-Sesquiphellandrol & & [18] \\
\hline 40 & Alcohol & trans- $\beta$-Sesquiphellandrol & & {$[18]$} \\
\hline 41 & Alcohol & $\beta$-Santalol & & [19] \\
\hline 42 & Alcohol & Zingiberol & & [19] \\
\hline 43 & Alcohol & tau-Cadinol & & {$[20]$} \\
\hline
\end{tabular}


TABle 1: Continued.

\begin{tabular}{|c|c|c|c|c|}
\hline No. & Type & Name & Structure & Reference \\
\hline 44 & Alcohol & Zingiberenol & & {$[21]$} \\
\hline 45 & Alcohol & 2-Pinen-5-ol & & {$[21]$} \\
\hline 46 & Alcohol & Bornyl methyl ether & & {$[21]$} \\
\hline 47 & Alcohol & Isoborneol & & {$[22]$} \\
\hline 48 & Alcohol & 2-Decanol & & {$[22]$} \\
\hline 49 & Alcohol & Fenchol & & {$[22]$} \\
\hline 50 & Alcohol & Linalool & & {$[23]$} \\
\hline 51 & Alcohol & Plinol & & {$[23]$} \\
\hline 52 & Alcohol & Camphenol & & {$[23]$} \\
\hline 53 & Alcohol & trans-2-Decen-1-ol & & {$[23]$} \\
\hline 54 & Alcohol & Hentriacontanol & & {$[24]$} \\
\hline 55 & Alcohol & 10-O- $\beta$-D-Glucopyranosyl-hydroxyl cineole & & {$[25]$} \\
\hline 56 & Aldoketone & Butanal & & {$[15]$} \\
\hline 57 & Aldoketone & Germacrone & & {$[15]$} \\
\hline 58 & Aldoketone & 2,6-Dimethylhept-5-enal & & {$[15]$} \\
\hline 59 & Aldoketone & 2-Heptanone & & {$[15]$} \\
\hline
\end{tabular}


Table 1: Continued.

\begin{tabular}{|c|c|c|c|c|}
\hline No. & Type & Name & Structure & Reference \\
\hline 60 & Aldoketone & (E)-Citral & & [15] \\
\hline 61 & Aldoketone & $(Z)$-Citral & & {$[15]$} \\
\hline 62 & Aldoketone & 2-Nonanone & & {$[15]$} \\
\hline 63 & Aldoketone & 3-((3E,5E)-Deca-3,5-dienyl)cyclopentanone & & {$[15]$} \\
\hline 64 & Aldoketone & $\beta$-Cyclocitral & & {$[15]$} \\
\hline 65 & Aldoketone & 2-Undecanone & & {$[15]$} \\
\hline 66 & Aldoketone & 1,7,7-Trimethylbicyclo[2.2.1]heptan-2-one & & [15] \\
\hline 67 & Aldoketone & $(1 R)-(-)$-Myrtenal & & {$[15]$} \\
\hline 68 & Aldoketone & $\beta$-Citronellal & & {$[15]$} \\
\hline 69 & Aldoketone & Crypton & & {$[15]$} \\
\hline 70 & Aldoketone & 4-Isopropylcyclohex-2-enone & & {$[15]$} \\
\hline 71 & Aldoketone & Camphor & & {$[15]$} \\
\hline 72 & Aldoketone & 6-Methyl-5-hepten-2-one & & [15] \\
\hline 73 & Aldoketone & trans,trans-Farnesal & & {$[15]$} \\
\hline 74 & Aldoketone & Hexanal & & {$[16]$} \\
\hline 75 & Aldoketone & Neral & & {$[17]$} \\
\hline
\end{tabular}


TABle 1: Continued.

\begin{tabular}{|c|c|c|c|c|}
\hline No. & Type & Name & Structure & Reference \\
\hline 76 & Aldoketone & Geranial & & [17] \\
\hline 77 & Aldoketone & Octanal & & {$[17]$} \\
\hline 78 & Aldoketone & Methyl heptenone & & {$[18]$} \\
\hline 79 & Aldoketone & Nonyl aldehyde & & [18] \\
\hline 80 & Aldoketone & Acetaldehyde & & {$[18]$} \\
\hline 81 & Aldoketone & Propionaldehyde & & {$[18]$} \\
\hline 82 & Aldoketone & Valeraldehyde & & {$[18]$} \\
\hline 83 & Aldoketone & Perillal & & [19] \\
\hline 84 & Aldoketone & (E)-Dodec-2-enal & & {$[21]$} \\
\hline 85 & Aldoketone & (Z)-3,7-Dimethylocta-3,6-dienal & & [21] \\
\hline 86 & Aldoketone & (E)-3,7-Dimethylocta-3,6-dienal & & {$[21]$} \\
\hline 87 & Aldoketone & (E)-Dec-2-enal & & {$[21]$} \\
\hline 88 & Aldoketone & Decanal & & {$[23]$} \\
\hline 89 & Aldoketone & Citronella & & [23] \\
\hline 90 & Aldoketone & 2-Octenal & & {$[21]$} \\
\hline 91 & Aldoketone & Octanal & & {$[26]$} \\
\hline 92 & Aldoketone & Acetone & & {$[26]$} \\
\hline 93 & Acid & L-Bornyl acetate & & {$[15]$} \\
\hline 94 & Acid & Geranic acid & & {$[15]$} \\
\hline 95 & Acid & Undecanoic acid & & {$[16]$} \\
\hline
\end{tabular}


TABle 1: Continued.

\begin{tabular}{|c|c|c|c|c|}
\hline No. & Type & Name & Structure & Reference \\
\hline 96 & Ester & Neryl acetate & & {$[15]$} \\
\hline 97 & Ester & Methyl 11-(cyclopent-2-enyl)undecanoate & & {$[15]$} \\
\hline 98 & Ester & Geranyl propionate & & {$[15]$} \\
\hline 99 & Ester & endo-Bornyl acetate & & {$[15]$} \\
\hline 100 & Ester & sec-Butyl acetate & & {$[15]$} \\
\hline 101 & Ester & 3,7-Dimethyl-2,6-octadienyl acetate & & [15] \\
\hline 102 & Ester & Neryl propionate & & {$[15]$} \\
\hline 103 & Ester & Geraniol formate & & [15] \\
\hline 104 & Ester & Myrtenyl acetate & & [15] \\
\hline 105 & Ester & Geranyl acetate & & [15] \\
\hline 106 & Ester & Formic acid ethyl ester & & {$[16]$} \\
\hline 107 & Ester & Ethyl butanoate & & {$[17]$} \\
\hline 108 & Ester & Citronellyl acetate & & [17] \\
\hline 109 & Ester & Heptyl acetate & & [17] \\
\hline 110 & Ester & Methyl acetate & & {$[18]$} \\
\hline 111 & Ester & Ethyl acetate & & [18] \\
\hline
\end{tabular}


Table 1: Continued.

\begin{tabular}{|c|c|c|c|c|}
\hline No. & Type & Name & Structure & Reference \\
\hline 112 & Ester & Butyl acetate & & {$[21]$} \\
\hline 113 & Ester & 2-Octyl acetate & & {$[21]$} \\
\hline 114 & Fat hydrocarbon & allo-Aromadendrene & & {$[15]$} \\
\hline 115 & Fat hydrocarbon & $\beta$-Sesquiphellandrene & & [15] \\
\hline 116 & Fat hydrocarbon & $\alpha$-Cedrene & & {$[15]$} \\
\hline 117 & Fat hydrocarbon & $\beta$-Thujene & & {$[15]$} \\
\hline 118 & Fat hydrocarbon & Cadina-5,8-diene & & [15] \\
\hline 119 & Fat hydrocarbon & Bicyclo[2.2.1]heptane & & [15] \\
\hline 120 & Fat hydrocarbon & (E)-2,7-Dimethyloct-3-en-5-yne & & {$[15]$} \\
\hline 121 & Fat hydrocarbon & (Z)-2,6-Dimethylocta-2,6-diene & & [15] \\
\hline 122 & Fat hydrocarbon & (E)-3,7-Dimethylocta-1,3,6-triene & & [15] \\
\hline 123 & Fat hydrocarbon & $\beta$-Phellandrene & & [15] \\
\hline 124 & Fat hydrocarbon & $\alpha$-Bergamotene & & {$[15]$} \\
\hline 125 & Fat hydrocarbon & $\alpha$-Gurjunene & & [15] \\
\hline 126 & Fat hydrocarbon & Sabinene & & [15] \\
\hline
\end{tabular}


Table 1: Continued.

\begin{tabular}{|c|c|c|c|c|}
\hline No. & Type & Name & Structure & Reference \\
\hline 127 & Fat hydrocarbon & $(+)$-Cyclosativene & & [15] \\
\hline 128 & Fat hydrocarbon & (Z)- $\beta$-Farnesene & & {$[15]$} \\
\hline 129 & Fat hydrocarbon & (E)- $\beta$-Farnesene & & {$[15]$} \\
\hline 130 & Fat hydrocarbon & $(Z, Z)-\alpha$-Farnesene & & [15] \\
\hline 131 & Fat hydrocarbon & Zingiberene & & {$[15]$} \\
\hline 132 & Fat hydrocarbon & $\alpha$-Farnesene & & [15] \\
\hline 133 & Fat hydrocarbon & (E)-5-Methylocta-1,6-diene & & {$[15]$} \\
\hline 134 & Fat hydrocarbon & 5-Methyloct-3-yne & & {$[15]$} \\
\hline 135 & Fat hydrocarbon & 7-Methylocta-3,4-diene & & {$[15]$} \\
\hline 136 & Fat hydrocarbon & $\gamma$-Elemene & & {$[15]$} \\
\hline 137 & Fat hydrocarbon & $\gamma$-Humulene & & {$[15]$} \\
\hline 138 & Fat hydrocarbon & Thujopsene & & {$[15]$} \\
\hline 139 & Fat hydrocarbon & $\beta$-Elemene & & [15] \\
\hline 140 & Fat hydrocarbon & $\beta$-Bisabolene & & {$[15]$} \\
\hline 141 & Fat hydrocarbon & $\alpha$-Pinene & & [15] \\
\hline 142 & Fat hydrocarbon & $\beta$-Pinene & & {$[15]$} \\
\hline
\end{tabular}


TABle 1: Continued.

\begin{tabular}{|c|c|c|c|c|}
\hline No. & Type & Name & Structure & Reference \\
\hline 143 & Fat hydrocarbon & Caryophyllene & & {$[15]$} \\
\hline 144 & Fat hydrocarbon & $\beta$-Caryophyllene & & {$[15]$} \\
\hline 145 & Fat hydrocarbon & Tricyclene & & {$[15]$} \\
\hline 146 & Fat hydrocarbon & Moslene & & {$[15]$} \\
\hline 147 & Fat hydrocarbon & Cedrene & & {$[15]$} \\
\hline 148 & Fat hydrocarbon & (-)-allo-Aromadendrene & & [15] \\
\hline 149 & Fat hydrocarbon & Neoclovene & & [15] \\
\hline 150 & Fat hydrocarbon & 3-Octyne & & [15] \\
\hline 151 & Fat hydrocarbon & 1-Octene & & [15] \\
\hline 152 & Fat hydrocarbon & $\beta$-Myrcene & & [15] \\
\hline 153 & Fat hydrocarbon & $\beta$-Eudesmene & & {$[15]$} \\
\hline 154 & Fat hydrocarbon & Eudesma-3,7(11)-diene & & {$[15]$} \\
\hline 155 & Fat hydrocarbon & Caryophyllene & & [15] \\
\hline 156 & Fat hydrocarbon & Bicyclo[3.1.1] heptane & & [15] \\
\hline 157 & Fat hydrocarbon & 1-Cyclopropylpentane & & [15] \\
\hline 158 & Fat hydrocarbon & 3-Carene & & [15] \\
\hline
\end{tabular}


Table 1: Continued.

\begin{tabular}{|c|c|c|c|c|}
\hline No. & Type & Name & Structure & Reference \\
\hline 159 & Fat hydrocarbon & 2-Carene & & {$[15]$} \\
\hline 160 & Fat hydrocarbon & (+)-Aromadendrene & & {$[15]$} \\
\hline 161 & Fat hydrocarbon & Fenchene & & {$[16]$} \\
\hline 162 & Fat hydrocarbon & $\delta$-Elemene & & [17] \\
\hline 163 & Fat hydrocarbon & D-Limonene & & {$[18,22]$} \\
\hline 164 & Fat hydrocarbon & $\beta$-Phellandrene & & {$[18,26]$} \\
\hline 165 & Fat hydrocarbon & 10-Epizonarene & & {$[18]$} \\
\hline 166 & Fat hydrocarbon & Octane & & [18] \\
\hline 167 & Fat hydrocarbon & Nonane & & {$[18]$} \\
\hline 168 & Fat hydrocarbon & $\alpha$-Bergamotene & & [19] \\
\hline 169 & Fat hydrocarbon & $\beta$-Bisabolene & & {$[20]$} \\
\hline 170 & Fat hydrocarbon & $\tau$-Epi- $\alpha$-selinene & & {$[20]$} \\
\hline 171 & Fat hydrocarbon & 4-Carene & & {$[22]$} \\
\hline 172 & Fat hydrocarbon & Camphene & & {$[23]$} \\
\hline 173 & Fat hydrocarbon & $\alpha$-Phellandrene & & {$[23]$} \\
\hline 174 & Fat hydrocarbon & (Z)-3,7-Dimethylocta-1,3,6-triene & & {$[27]$} \\
\hline
\end{tabular}


Table 1: Continued.

\begin{tabular}{|c|c|c|c|c|}
\hline No. & Type & Name & Structure & Reference \\
\hline 175 & Fat hydrocarbon & Germacrene & & {$[27]$} \\
\hline 176 & Fat hydrocarbon & $\delta$-Cadinene & & {$[26]$} \\
\hline 177 & Fat hydrocarbon & $\alpha$-Cubebene & & {$[26]$} \\
\hline 178 & Fat hydrocarbon & $\alpha$-Copaene & & {$[26]$} \\
\hline 179 & Arene & $\alpha$-Curcumene & & {$[15]$} \\
\hline 180 & Arene & 2-Isopropyltoluene & & {$[15]$} \\
\hline 181 & Arene & $o$-Cymene & & {$[15]$} \\
\hline 182 & Arene & Styrene & & {$[17]$} \\
\hline 183 & Arene & Methylbenzene & & {$[17]$} \\
\hline 184 & Arene & Cumene & & {$[18]$} \\
\hline 185 & Arene & p-Cymene & & {$[19]$} \\
\hline 186 & Others & p-Cymen-8-ol & & {$[15]$} \\
\hline 187 & Others & 2-Acetoxy-1,8-cineole & & {$[17]$} \\
\hline 188 & Others & Diethyl sulphide & & {$[18]$} \\
\hline 189 & Others & Ethyl isopropyl sulphide & & {$[18]$} \\
\hline 190 & Others & Methyl allyl sulphide & & {$[18]$} \\
\hline
\end{tabular}


TABLE 1: Continued.

\begin{tabular}{l} 
No. Type \\
\hline 191 \\
192 Others \\
194 Others \\
Others \\
Others
\end{tabular}

2.3. Diarylheptanoids. Diarylheptanoid is a group of compounds with 1,7-disubstituted phenyl groups and heptane skeletons in its parent structure. Currently, it can be divided into linear diphenyl heptane and cyclic diphenyl heptane compounds with antioxidant activity [53]. The structural formulas are shown in Table 3.

\subsection{Others}

2.4.1. Proteins and Amino Acids. ZOR contains a variety of amino acids, including glutamate, aspartic acid, serine, glycine, threonine, alanine, cystine, valine, methionine, isoleucine, leucine, tyrosine, phenylalanine, lysine, histidine, arginine, proline [22, 60], and tryptophan [51].

2.4.2. Sugars. ZOR also contains polysaccharides [44], cellulose, and soluble sugar.

2.4.3. Organic Acids. ZOR contains oxalic acid, tartaric acid, lactic acid, acetic acid, citric acid, succinic acid, formic acid, and malonic acid [61].

2.4.4. Inorganic Elements. ZOR has been shown to contain more than 20 inorganic elements such as $\mathrm{K}, \mathrm{Mg}, \mathrm{Ga}, \mathrm{Mn}, \mathrm{P}$, $\mathrm{Al}, \mathrm{Zn}, \mathrm{Fe}$, and $\mathrm{Ba}[44]$.

\section{Discussion}

Various gingers have different regions and chemical compositions. Jolad [30] conducted quantitative analysis on the extracts of dichloromethane from Chinese white ginger and Japanese turmeric and found that the highest content of 6 -gingerol was $28 \%$ and $34 \%$, respectively. The next highest concentrations were 8-gingerol and 10-gingerol, and the lowest content of 6 -shogaol was only $0.35 \%$. Onyenekwe
[62] determined that the main components of the volatile oils of Nigerian ginger were terpenoids such as zingiberene (29.5\%) and $\beta$-sesquiphellandrene (18.4\%), which were quite different from those of ginger grown in other regions. Another study showed the volatile oil content of ginger grown in five different areas of China (Shandong Laiwu, Anhui Tongling, Shandong Anqiu, Guangdong Guangzhou, and Hunan Rucheng) was $0.13 \%, 0.23 \%, 0.30 \%, 0.14 \%$, and $0.17 \%$ [63], respectively. 6-Gingerol is often the quality standard for ginger, where the ginger found in Qianwei, Sichuan Province, shows a higher effective content of 6gingerol than that of the pharmacopoeia standard of the People's Republic of China [64, 65]. The concentrations of 6-gingerol and 6-zingiberol of ginger grown in different regions of China vary greatly, which may be related to the growth environment [66]. Mature and fresh ginger extracts contain the same chemical components, but the difference is in the relative content of each component. Ginger oleoresin in mature ginger is significantly higher than that in fresh ginger. In aromatic terpenoids, the contents of 2-acetoxy1,8-cineole, $\beta$-citronellal, citral, geraniol, geranyl acetate, and zingiberene in mature ginger are lower than those in fresh ginger. The relative content of $\alpha$-curcumene in mature ginger was higher than that in fresh ginger. In spicy gingerol compounds, the relative content of gingerol in mature ginger is higher than that in fresh ginger, which may be the result of further synthesis and accumulation of gingerol components in the process of continued growth of mature ginger in the second year [48]. The varieties of ginger with the highest oil content are Laiwu ginger, Japanese ginger, Shannong 1 ginger, Shannong 2 ginger, and Anqiu big ginger, with concentrations of $4.56 \%, 4.42 \%, 4.52 \%, 4.50 \%$, and $4.35 \%$, respectively. Average oil contents of $3.45 \%$ and $3.16 \%$ were found in Jinchang ginger and Chinger, respectively. The lowest oil extraction rates were found in Anqiu small ginger, Fangzhou ginger, and Jinshi ginger, which were $2.95 \%, 2.60 \%$, and $1.55 \%$, respectively [48]. 
TABLE 2: Gingerols in ZOR.

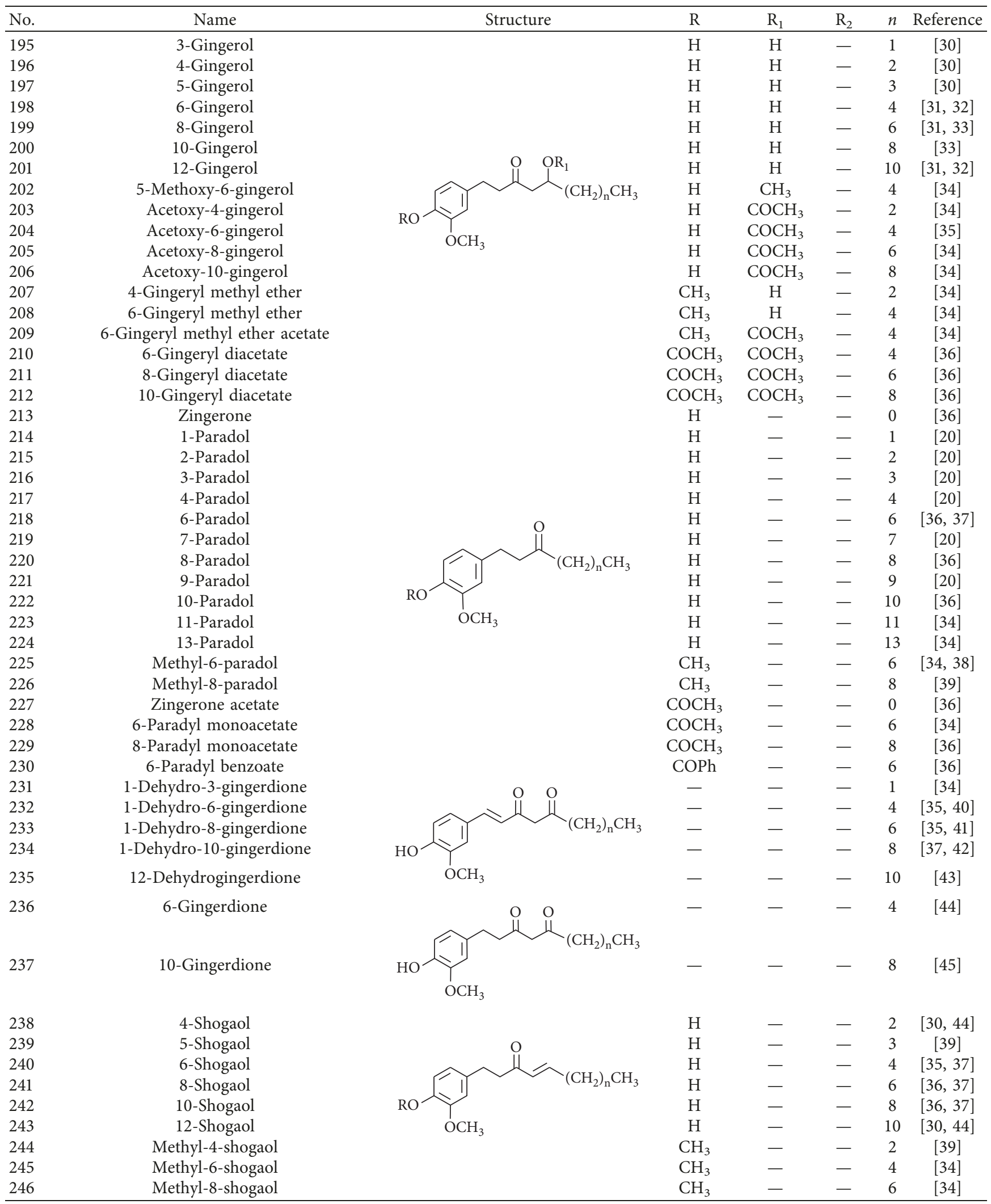


TABle 2: Continued.

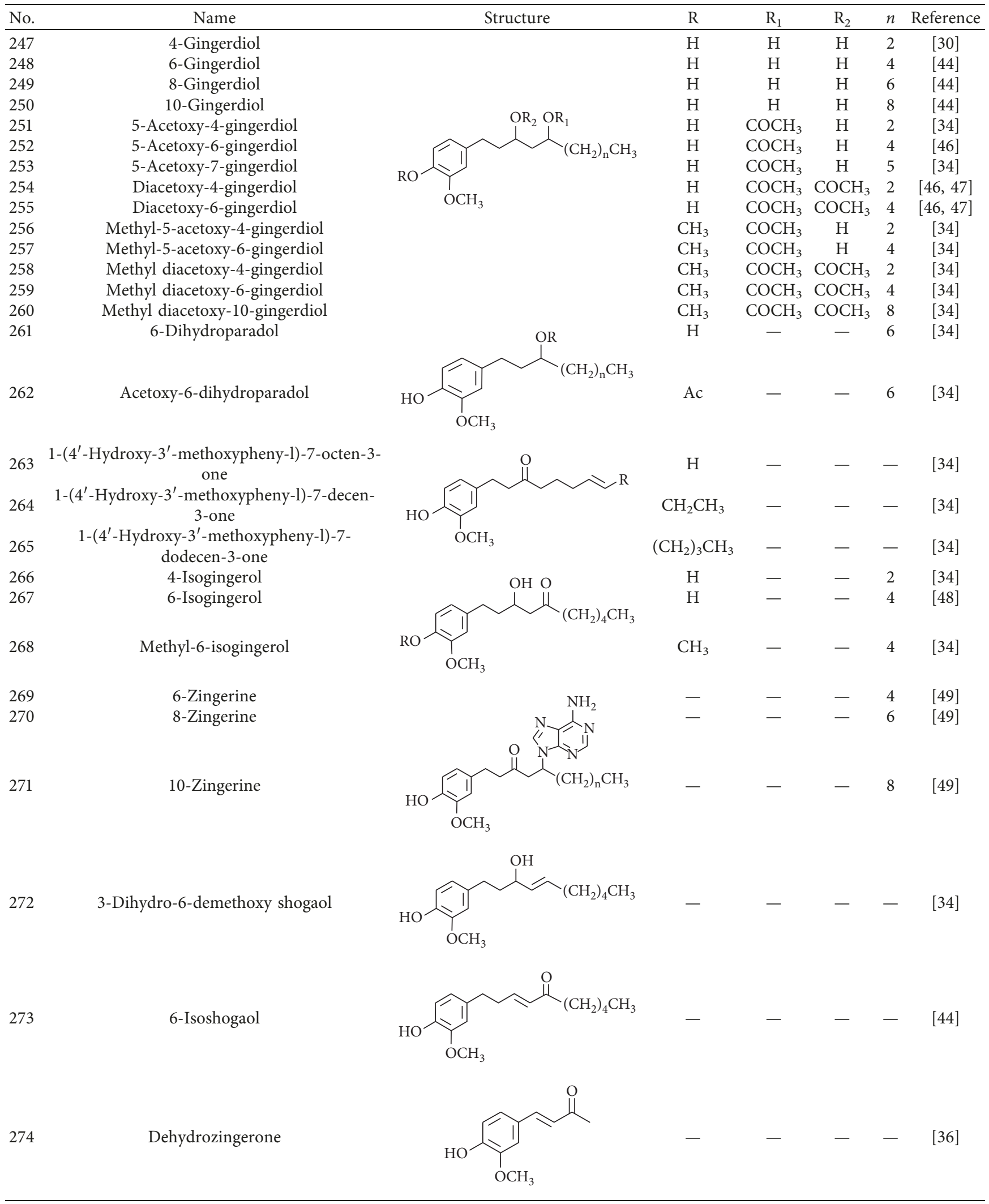


TABLE 2: Continued.

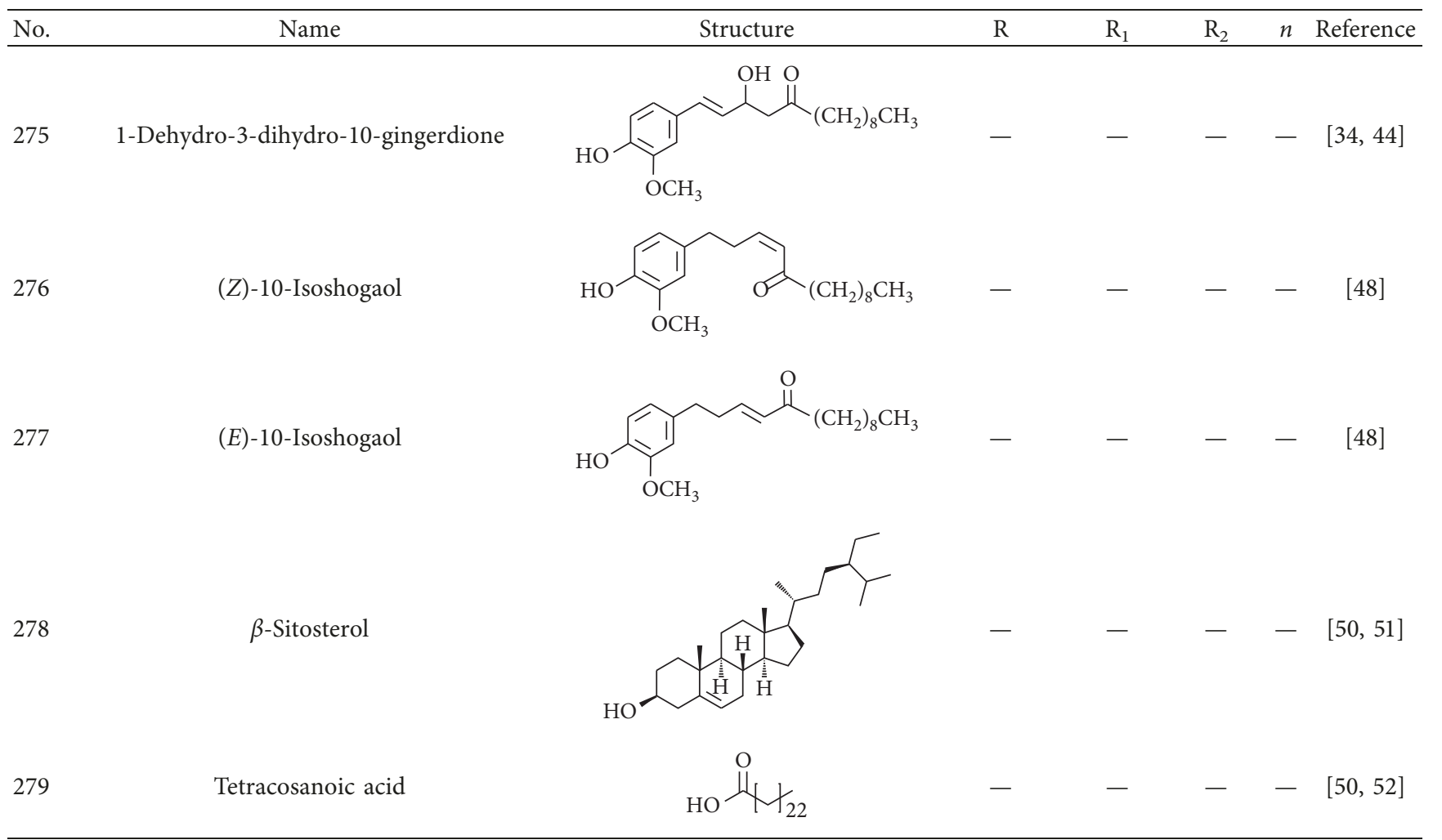

Ginger, as a kind of food and medicine, has many functions, such as antioxidant, anti-inflammatory, antimicrobial, anticancer, antiobesity, antidiabetic, antinausea, antiemetic, antiallergic, neuroprotective, hepatoprotective, cardiovascular protective, and respiratory protective activities [67]. Currently, most studies of the bioactive components of ginger focus on ginger volatile oil, gingerol, shogaol, and zingerone compounds. Ginger essential oil can effectively improve the antioxidant capacity of the liver, reduce inflammatory response, and protect against fatty liver [68]. The antioxidant compounds in ginger are primarily gingerol and diarylheptanoid. Substituents on alkyl chains contribute to free radical scavenging and oxidation inhibition of lipids [69]. Antioxidant activity is typically derived from gingerols, shogaols, and some related phenolic ketone derivatives [70]. Gingerols are spicy ingredients in which 6-gingerol shows the highest biological activity, so 6-gingerol is often used as an indicator of ginger quality [71]. 6-Gingerol has been used to inhibit angiogenesis in vivo and in vitro [72]. It has been shown to have anticancer and antigastric ulcer properties while suppressing central nervous stimulation and various pharmacological activities [73, 74] . 6-Gingerol has been used to treat tumors by regulating the apoptosis gene by reversing the abnormal expression of tumor cell genes. It can also affect the apoptosis signal transduction pathway and induce apoptosis [75]. 8-Gingerol and 10-gingerol have good inhibitory effects on the activity of various tumor cells, where the inhibitory effects are somewhat different. The two may affect the phosphorylation level of the MAPK pathway proteins ERK and P38, leading to G1 phase arrest of breast cancer cells, thus applying inhibitory effects on the proliferation of tumor cells [76]. The main components of strong heart are gingerol and 6-shogaol [77]. The effects of 6gingerol and 6-shogaol on blood pressure have been shown to induce a hypotensive effect at low doses, while high doses have shown a three-phase reaction. Initially, blood pressure drops rapidly, then rises, and then provides a hypotensive effect at later stages [78]. Ginger polysaccharide has biological activities such as antitumor, hypoglycemic, lipidlowering, immune regulation, antivirus, and antifatigue [79].

\section{Conclusion}

ZOR is a widely used drug and food in clinical and daily life and has been used in the prevention and treatment of the digestive, circulatory, respiratory, and central nervous system diseases and other diseases. In this paper, the chemical constituents found in ZOR in recent years are summarized, and the results show that more than 300 chemical constituents are identified from the extracts of $\mathrm{ZOR}$, including 194 types of volatile oil, 85 types of gingerol, and 28 types of diarylheptanoids compounds. From this, it can be clearly observed that ZOR has a complex chemical composition. The interactions between the components provide the clinical effects; therefore, it is necessary to further study the chemical composition and pharmacological action of ginger, for further applications. Exploring the mechanism by which different components perform the same effects is a new way to develop drugs in the future; for example, 4-terpineol and beta-sitosterol can act on the two targets of the 5- 
TABLE 3: Diarylheptanoids in ZOR.

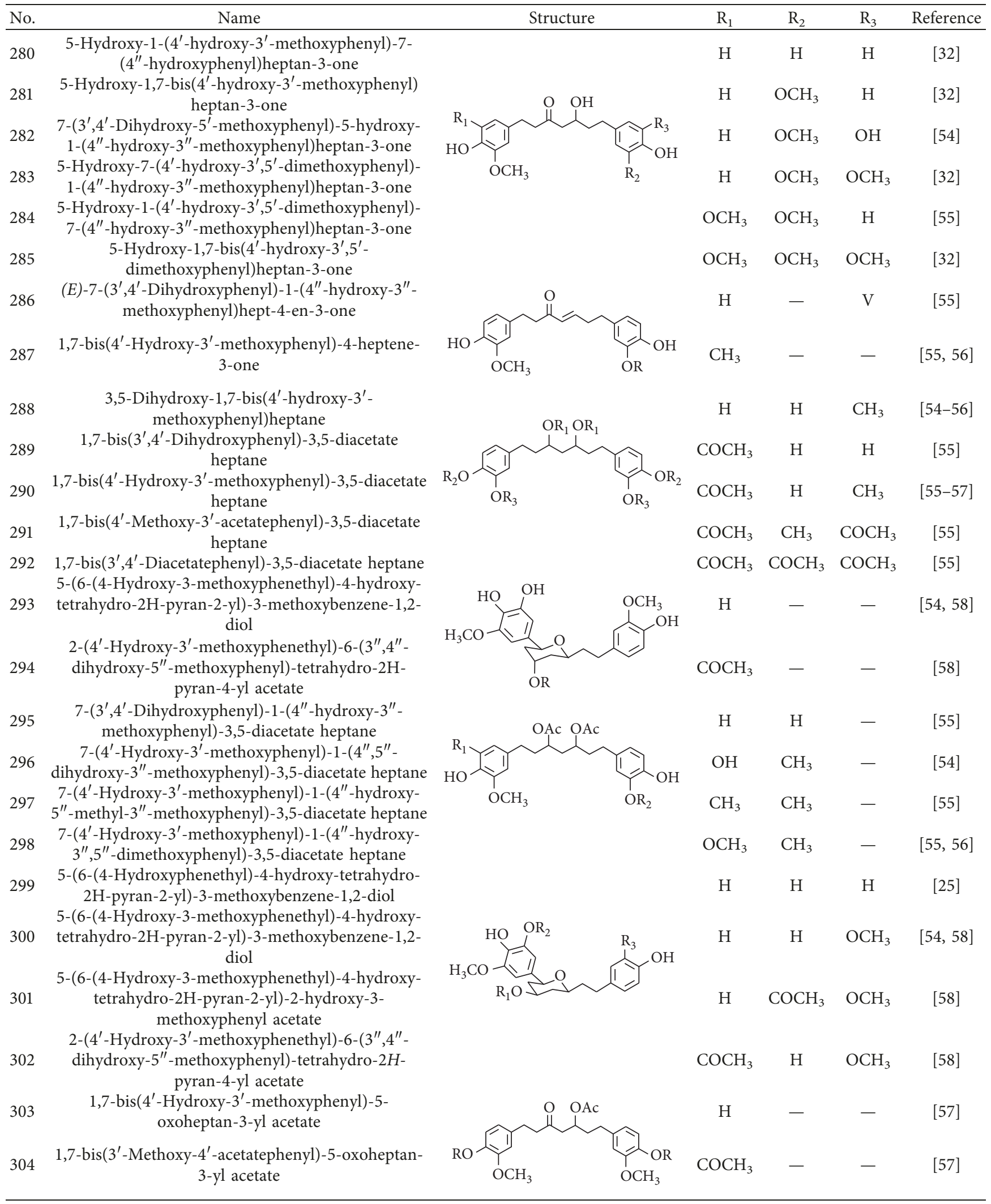


TABLE 3: Continued.

No.

hydroxytryptamine receptor $3 \mathrm{~A}$ and the mu-type opioid receptor, respectively, and provide corresponding therapeutic effects on diarrhea and dysentery. This can provide ideas for the research and development of new drugs and lay a foundation for further applications of ZOR.

\section{Conflicts of Interest}

The authors declare that they have no conflicts of interest.

\section{Acknowledgments}

This work was financially supported by the Key Research and Development Technology of Shandong Province (Industry Key Technology) (2016CYJS08A01).

\section{References}

[1] National Pharmacopoeia Commission, Pharmacopoeia of the People's Republic of China: 2015 Edition, China Pharmaceutical Science and Technology Press, Beijing, China, 2015.

[2] X. F. Wang, G. T. Wu, T. H. Niu et al., "Chemistry, pharmacology and application of ginger," Chinese Fruit and Vegetable, vol. 36, no. 6, pp. 23-29, 2016.

[3] W. Y. Hu, R. P. Zhang, L. P. Tang et al., "Advances in chemical and pharmacological research on ginger," Chinese Folk Medicine, vol. 9, pp. 10-14, 2008.

[4] M. M. Zhu, D. Liu, K. X. Lu et al., "Research progress on pharmacological action of ginger horseradish," Journal of Hubei Institute of Medicine, vol. 37, no. 4, pp. 390-394, 2018.

[5] Y. J. Sun, "Research progress on pharmacological action of Ginger," Modern Journal of Integrated Chinese and Western Medicine, vol. 16, no. 4, pp. 561-564, 2007.

[6] Y. Chen, Y. Y. Ni, and T. Y. Cai, "Study on comprehensive utilization and deep processing of ginger extract," Food Industry Technology, vol. 21, no. 4, pp. 76-78, 2000.

[7] J. P. Li, "Application of ginger extract in toothpaste," Toothpaste Industry, no. 2, pp. 10-11, 2008.

[8] Z. Y. Peng, W. Huang, Y. F. Guan et al., "Development of ginger health jelly," Food and Fermentation Technology, vol. 45, no. 4, pp. 74-76, 2009.
[9] W. M. Dong, Q. Y. Tang, and W. Yuan, "Study on processing technology of ginger brown sugar Beverage," Modern Food Technology, vol. 23, no. 2, pp. 57-58, 2007.

[10] B. Zhan and F. Z. Wang, "Processing technology of Ginger Beverage series products," Agro-Processing, vol. 1, p. 77, 2013.

[11] H. Wohlmuth, M. K. Smith, L. O. Brooks, S. P. Myers, and D. N. Leach, "Essential oil composition of diploid and tetraploid clones of ginger (Zingiber officinale Roscoe) grown in Australia," Journal of Agricultural and Food Chemistry, vol. 54, no. 4, pp. 1414-1419, 2006.

[12] W. S. He, Y. X. Yan, and B. J. Guo, "General situation of study on chemical constituents and bioactivity of ginger," Chinese Herbal Medicine, vol. 24, no. 5, pp. 376-379, 2001.

[13] S. D. Jolad, R. C. Lantz, G. J. Chen, R. B. Bates, and B. N. Timmermann, "Commercially processed dry ginger (Zingiber officinale): composition and effects on LPS-stimulated $\mathrm{PGE}_{2}$ production," Phytochemistry, vol. 66, no. 13, pp. 1614-1635, 2005.

[14] E. Langner, S. Greifenberg, and J. Gruenwald, "Ginger: history and use," Advances in Therapy, vol. 15, pp. 25-44, 1998.

[15] J. N. Tan, "GC-MS Study on chemical constituents of volatile oils from ginger in different producing areas," Asia-Pacific Traditional Medicine, vol. 7, no. 4, pp. 23-25, 2011.

[16] H. Zhang, J. C. Yan, H. G. Zhanget et al., "Extraction of volatile oil from ginger and analysis of its chemical constituents by gas chromatography-mass spectrometry," Analytical Chemistry, vol. 24, no. 3, pp. 348-352, 1996.

[17] X. Pang, J. Cao, D. Wang, J. Qiu, and F. Kong, "Identification of ginger (Zingiber officinale Roscoe) volatiles and localization of aroma-active constituents by GC-olfactometry," Journal of Agricultural and Food Chemistry, vol. 65, no. 20, pp. 41404145, 2017.

[18] V. S. Govindarajan and D. W. Connell, "Ginger-chemistry, technology, and quality evaluation: Part 1," CRC Critical Reviews in Food Science and Nutrition, vol. 17, no. 1, pp. 1-96, 1983.

[19] Z. K. Lin and Y. F. Hua, "Study on chemical constituents of ginger essential oil in Sichuan," Organic Chemistry, vol. 6, pp. 444-448, 1987.

[20] J. P. Li, Y. S. Wang, H. Ma et al., "Comparative study on the main chemical components of dried ginger and ginger," Chinese Journal of Chinese Medicine, vol. 26, no. 11, pp. 748-751, 2001. 
[21] O. Nishimura, "Identification of the characteristic odorants in fresh Rhizomes of ginger (Zingiber officinale Roscoe) using aroma extract dilution analysis and modified multidimensional gas chromatography-mass spectroscopy," Journal of Agricultural and Food Chemistry, vol. 43, no. 11, pp. 29412945, 1995.

[22] T. Jia, R. L. Xiao, and H. Jiao, "Analysis of volatile components in rhizome zingibers, Zingiber officinale Roscoe and ginger pee by GC-MS and chemometric resolution," JCMRD, vol. 1, no. 2, pp. 47-53, 2012.

[23] J. F. Wu, C. Zhang, X. M. Zhang et al., "Extraction and composition analysis of ginger flavor substances," Deep Processing of Fruits and Vegetables, vol. 22, no. 3, pp. 94-99, 2006.

[24] W. D. Xuan, J. Bian, B. Yuan et al., "Study on chemical constituents of ginger," Chinese Herbal Medicine, vol. 39, no. 11, pp. 1616-1619, 2008.

[25] Y. Zhao, Q. F. Tao, R. P. Zhang et al., "Two new compounds from Zingiber officinale," Chinese Chemical Letters, vol. 18, no. 10, pp. 1247-1249, 2007.

[26] M. K. Kim, M. S. Na, J. Hong, and S. T. Jung, "Volatile flavor components of Korean ginger (Zingiber officinale Roscoe) extracted with liquid carbon," Hanguk Nonghwa Hakhorchi, vol. 35, no. 1, pp. 59-63, 1992.

[27] Q. X. Cui and Y. Dong, "GC-MS analysis of chemical constituents of ginger volatile oil," Journal of Liaocheng University (Natural Science Edition), vol. 19, no. 2, pp. 43-45, 2006.

[28] C. J. Lu, M. Ou, and N. S. Wang, "Summary of chemical composition analysis of ginger," New Drugs and Clinical Pharmacology of Traditional Chinese Medicine, vol. 14, no. 3, pp. 215-217, 2003.

[29] H. L. Luo, "Extraction, separation and component study of the efficacy components of ginger," M.S. dissertation, Anhui Agricultural University, Anhui, China, 2010.

[30] H. Xiong, "Comparative study of components in ginger extracts by different extraction methods," M.S. dissertation, Xihua University, Sichuan, China, 2006.

[31] G. Vernin and C. Parkanyl, "Chemistry of ginger," in Ginger: The Genus Zingiber, P. N. Ravindran and K. Nirmal Babu, Eds., CRC Press, New York, NY, USA, pp. 87-180, 2005.

[32] X. S. Huang, R. A. Yan, and J. Z. Wu, "A review of the bioactivity of ginger phenol," Journal of Jinan University, vol. 26, no. 3, pp. 434-435, 2005.

[33] E. Katsuya, K. Emi, and O. Yoshiteru, "Structures of antifungal diarylheptenones, gingerenones $\mathrm{A}, \mathrm{B}, \mathrm{C}$ and isogingerenone B, isolated from the rhizomes of Zingiber officinale," Phytochemistry, vol. 29, no. 3, pp. 797-799, 1990.

[34] S. D. Jolad, R. C. Lantz, A. M. Solyom, G. J. Chen, R. B. Bates, and B. N. Timmermann, "Fresh organically grown ginger (Zingiber officinale): composition and effects on LPS-induced $\mathrm{PGE}_{2}$ production," Phytochemistry, vol. 65, no. 13, pp. 1937-1954, 2004.

[35] L. Wang, L. Fang, H. Q. Zhao et al., "High performance liquid chromatography-electrospray four-stage mass spectrometry analysis of ginger horseradish compounds in ginger," Chinese Journal of Traditional Chinese Medicine, vol. 36, no. 24, pp. 3467-3471, 2011.

[36] D. W. Connell and R. McLachlan, "Natural pungent compounds: IV. Examination of the gingerols, shogaols, paradols and related compounds by thin-layer and gas chromatography," Journal of Chromatography A, vol. 67, no. 1, pp. 29-35, 1972.
[37] J. Zhang, Y. S. Chang, C. Zeng et al., "Study on chemical constituents in ginger extract," Anhui Agricultural Science, vol. 43, no. 25, pp. 287-290, 2015.

[38] A. M. Galal, "Antimicrobial activity of 6-paradol and related compounds," International Journal of Pharmacognosy, vol. 34, no. 1, pp. 64-69, 1996.

[39] S. B. Tan, "Study on water-soluble chemical constituents of ginger and shear," M.S. dissertation, Lanzhou University of Technology, Gansu, China, 2017.

[40] R. Charles, S. N. Garg, and S. Kumar, "New gingerdione from the rhizomes of Zingiber officinale," Fitoterapia, vol. 71, no. 6, pp. 716-718, 2000.

[41] K. Masanori, U. U. Kaoru, H. Tatsuo et al., "Cell differentiation inducers and antiandrogenic active compounds from Zingiberis rhizome," Natural Medicines, vol. 56, no. 2, pp. 47-50, 2002.

[42] X.-G. He, M. W. Bernart, L.-Z. Lian, and L.-Z. Lin, "Highperformance liquid chromatography-electrospray mass spectrometric analysis of pungent constituents of ginger," Journal of Chromatography A, vol. 796, no. 2, pp. 327-334, 1998.

[43] Y. A. Han, C. W. Song, W. S. Koh et al., "Anti-inflammatory effects of theZingiber officinaleroscoe constituent 12-dehydrogingerdione in lipopolysaccharide-stimulated raw 264.7 cells," Phytotherapy Research, vol. 27, no. 8, pp. 1200-1205, 2013.

[44] W. Z. Zhao, R. X. Zhang, Z. P. Yu et al., "Research progress on chemical constituents and bioactivity of Ginger," Food Industry Technology, vol. 37, no. 11, pp. 383-387, 2016.

[45] E. Koh, H. Kim, S. Kim et al., "Modulation of macrophage functions by compounds isolated from Zingiber officinale," Planta Medica, vol. 75, no. 02, pp. 148-151, 2009.

[46] H. Kikuzaki, S.-M. Tsai, and N. Nakatani, "Gingerdiol related compounds from the rhizomes of Zingiber officinale," Phytochemistry, vol. 31, no. 5, pp. 1783-1786, 1992.

[47] Y. Masada, T. Inoue, K. Hashimoto, M. Fujioka, and C. Uchino, "Studies on the constituents of ginger (Zingiber officinale Roscoe) by GC-MS," Yakugaku Zasshi, vol. 94, no. 6, pp. 735-738, 1974.

[48] K. Y. Zhan, "Chemical composition analysis of ginger oil and study on isolation and purification of ginger horseradish," M.S. dissertation, Shandong Agricultural University, Shandong, China, 2009.

[49] J. Juan, H. P. Zhang, T. E. Prisinzano, L. A. Mitscher, and B. N. Timmermann, "Identification of unprecedted purinecontaining compounds, the zingerines, from ginger rhizomes(Zingiber officinale Roscoe) using a phase-trafficking approach," Phytochemistry, vol. 72, no. 9, pp. 935-941, 2011.

[50] J. W. Purseglove, E. G. Brown, C. L. Green, and S. R. J. Robbins, "Spices," M.S. dissertation, Longman, New York, NY, USA, 1981.

[51] J. Li, "Processing principle of ginger," M.S. dissertation, Henan College of Traditional Chinese Medicine, Henan, China, 2007.

[52] D. Liu, C. H. Zhang, R. H. An et al., "Research progress on extraction and application of main bioactive components of ginger," Food Industry Science and Technology, vol. 37, no. 20, pp. 391-393, 2016.

[53] X. Wang, "Research progress on active sites and components of ginger," Research on Traditional Chinese Medicine, vol. 22, no. 12, pp. 53-55, 2009.

[54] L. X. Yang, C. X. Zhou, K. X. Huang et al., "Study on antioxidant and cytotoxic activity of diphenyl heptane compounds in Ginger," Chinese Journal of Traditional Chinese Medicine, vol. 34, no. 3, pp. 319-322, 2009. 
[55] H. Kikuzaki, M. Kobayashi, and N. Nakatani, "Diarylheptanoids from rhizomes of Zingiber officinale," Phytochemistry, vol. 30, no. 11, pp. 3647-3651, 1991.

[56] H. Kikuzaki and N. Nakatani, "Antioxidant effects of some ginger constituents," Journal of Food Science, vol. 58, no. 6, pp. 1407-1410, 1993.

[57] J. P. Ma, X. L. Jin, L. Yang et al., "Two new diarylheptanoids from the rhizomes of zingiber officinale," Chinese Chemical Letters, vol. 15, no. 11, pp. 1306-1308, 2004.

[58] H. Kikuzaki and N. Nakatani, "Cyclic diarylheptanoids from rhizomes of Zingiber officinale," Phytochemistry, vol. 43, no. 1, pp. 273-277, 1996.

[59] J. C. Luo, Y. F. Feng, and X. Ji, "Research progress of natural linear diphenyl heptane compounds," Chinese Herbal Medicine, vol. 39, no. 12, pp. 1913-1916, 2012.

[60] Y. F. Zhang and Z. C. Ma, "Ingredients and applications of ginger," Chemistry Teaching, vol. 8, pp. 73-80, 2012.

[61] S. H. Li, F. Z. Chen, Z. Liu et al., "Determination of Vc, nitrate, nitrite, total sugar, organic acid content in greenhouse ginger," Anhui Agricultural Science, vol. 34, no. 14, pp. 3346-3347, 2006.

[62] P. C. Onyenekwe and S. Hashimoto, "The composition of the essential oil of dried Nigerian ginger (Zingiber officinale Roscoe)," European Food Research and Technology, vol. 209, no. 6, pp. 407-410, 1999.

[63] W. M. Zhang, H. F. Jiang, and J. Zhang, "Study on gas chromatographic fingerprints of different aromatic parts of ginger," China Wild Plant Resources, vol. 22, no. 5, pp. 53-55, 2003.

[64] National Pharmacopoeia Commission, Pharmacopoeia of the People's Republic of China (Part I), China Medical Science and Technology Press, Beijing, China, 2015.

[65] X. F. Liao, Y. Y. Ying, W. Y. Guo et al., "Analysis of the characteristics of qianwei ginger and determination of its main components," Chinese Journal of Traditional Chinese Medicine, vol. 34, no. 6, pp. 2680-2683, 2019.

[66] W. D. Xuan, J. Bian, C. W. Wang et al., "Comparison of extraction methods and quality control of 6-gingerol in ginger," Chinese Journal of Pharmacy of the People's Liberation Army, vol. 24, no. 4, pp. 329-331, 2008.

[67] Q.-Q. Mao, X.-Y. Xu, S.-Y. Cao et al., "Bioactive compounds and bioactivities of ginger (Zingiber officinale Roscoe)," Foods, vol. 8, no. 6, p. 185, 2019.

[68] Y.-S. Lai, W.-C. Lee, Y.-E. Lin et al., "Ginger essential oil ameliorates hepatic injury and lipid accumulation in high fat diet-induced nonalcoholic fatty liver disease," Journal of Agricultural and Food Chemistry, vol. 64, no. 10, pp. 20622071, 2016.

[69] Y. Masuda, H. Ikuzaki, M. Hisamoto, and N. Nakatani, "Antioxidant properties of gingerol related compounds from ginger," Biofactors, vol. 21, no. 1-4, pp. 293-296, 2004.

[70] N. Liu, G. C. Huo, and L. Zhang, "Effects of ginger on lipid peroxidation in hyperlipidemia rats," Health Research, vol. 32, no. 1, pp. 22-23, 2003.

[71] X. H. Zhang and H. X. Liu, "Research progress of gingerol," Journal of Guangxi Normal University, vol. 26, no. 1, pp. 110-113, 2009.

[72] E.-C. Kim, J.-K. Min, T.-Y. Kim et al., "[6]-Gingerol, a pungent ingredient of ginger, inhibits angiogenesis in vitro and in vivo," Biochemical and Biophysical Research Communications, vol. 335, no. 2, pp. 300-308, 2005.

[73] R. C. Lantz, G. J. Chen, M. Sarihan, A. M. Sólyom, S. D. Jolad, and B. N. Timmermann, "The effect of extracts from ginger rhizome on vegetation," Phytomedicine, vol. 14, no. 2-3, pp. 123-128, 2007.

[74] H. M. Qian, M. Wang, and Z. X. Su, "Preliminary experimental study on anti-tumor effects of ginger extract," Jiangsu Pharmaceutical \& Clinical Research, vol. 7, no. 3, pp. 14-16, 1999.

[75] J. Xu, "Research progress on anti-tumor effects of ginger," Journal of Youjiang Medical College for Nationalities, vol. 37, no. 3, pp. 496-497, 2015.

[76] X. Liu, H. W. Zhang, R. Q. Fu et al., "Anti-tumor effects and mechanism of active components of gingerol in ginger," Journal of Third Military Medical University, vol. 39, no. 9, pp. 884-890, 2017.

[77] C. J. Lu, M. Ou, and N. S. Wang, "Pharmacological effects of ginger on cardiovascular and cerebrovascular system," Chinese Medicine New Drug and Clinical Pharmacology, vol. 14, no. 5, pp. 356-357, 2003.

[78] M. Suekawa, A. Ishige, K. Yuasa, K. Sudo, M. Aburada, and E. Hosoya, "Pharmacological studies on Ginger. I. Pharmacological actions of pungent constituents, (6)-gingerol and (6)-shogaol," Journal of Pharmacobio-Dynamics, vol. 7, no. 11, pp. 836-848, 1984.

[79] J. A. Wu, X. Y. Wang, K. L. Wang et al., "Research progress on nutritional value and pharmacological action of ginger," Food Industry, vol. 40, no. 2, pp. 237-239, 2019. 


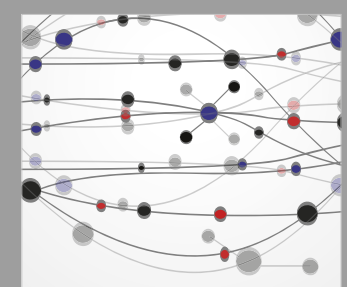

The Scientific World Journal
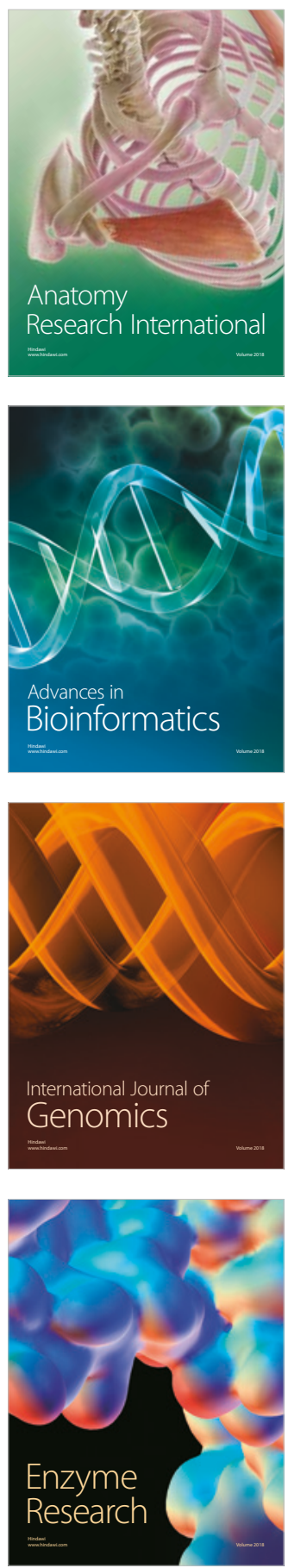
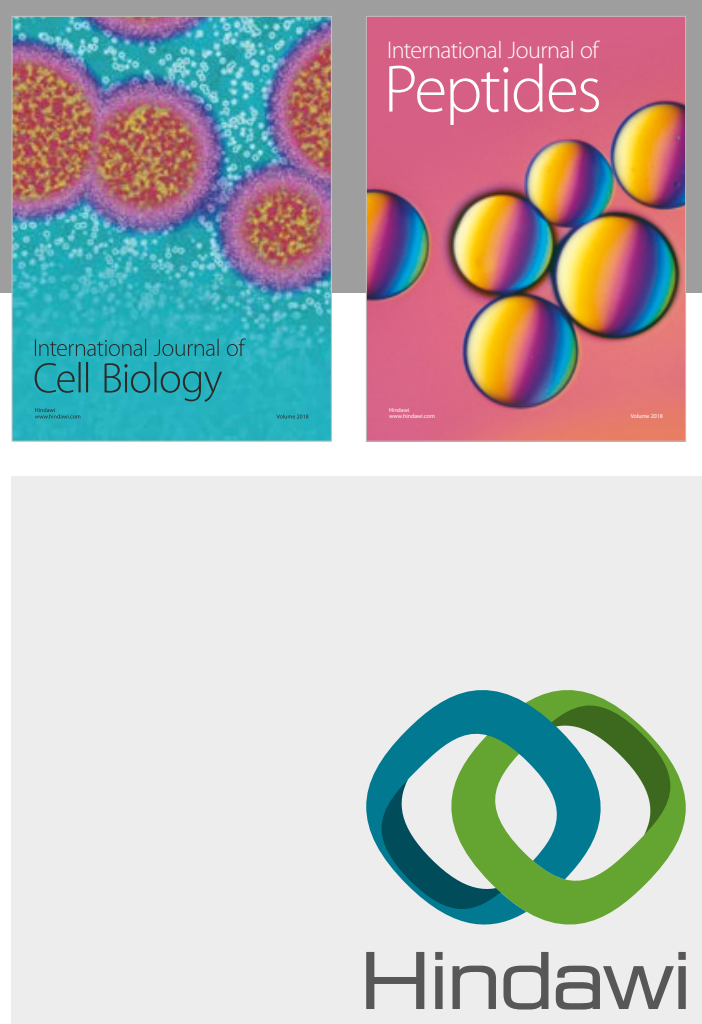

Submit your manuscripts at

www.hindawi.com
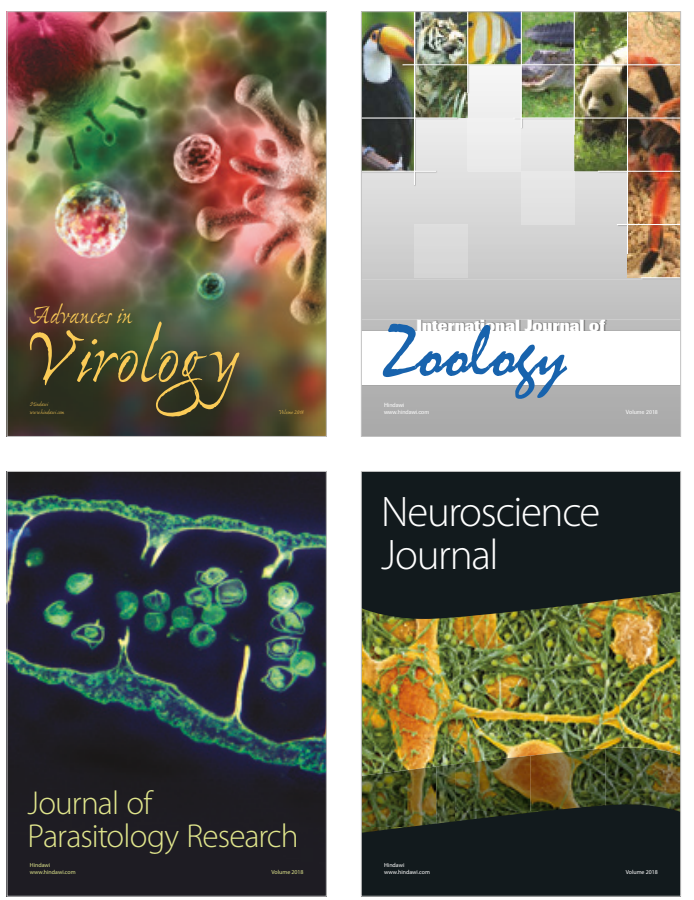
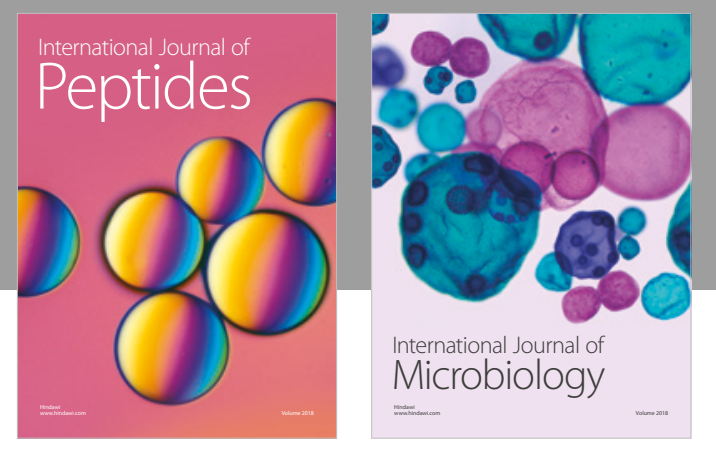

nternational Journal of Microbiology
Journal of
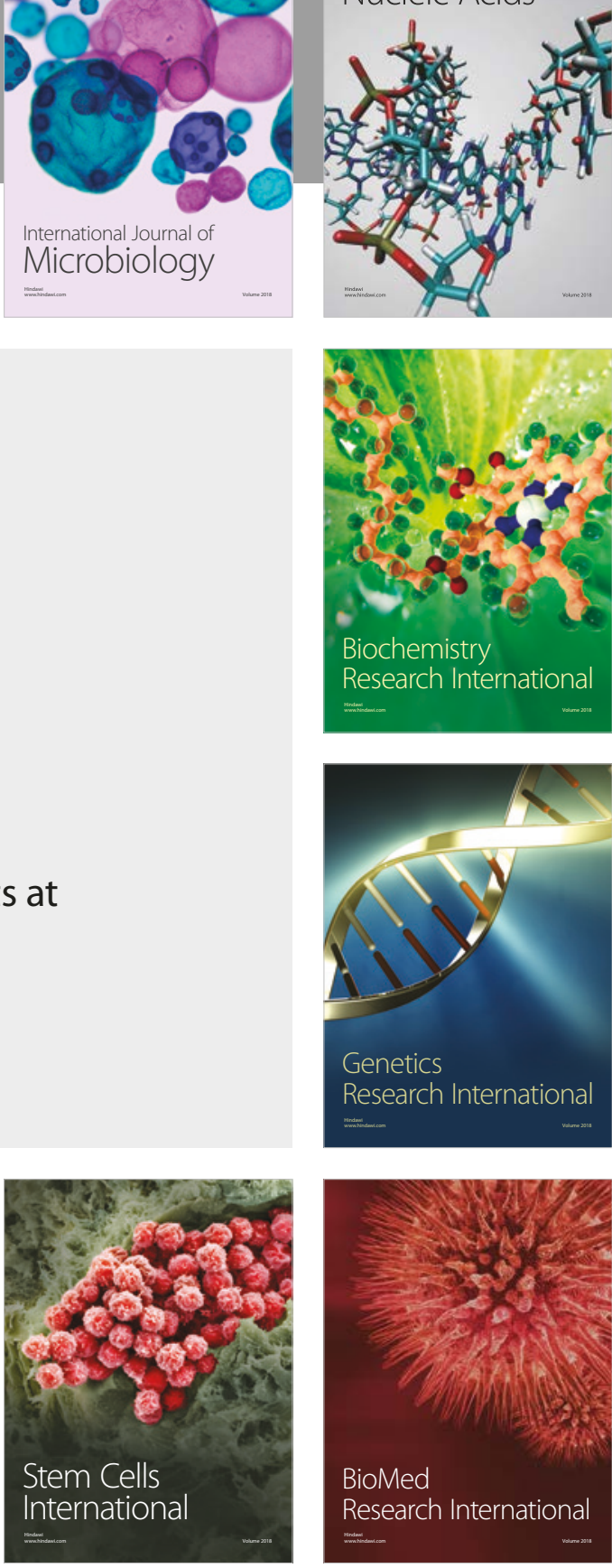
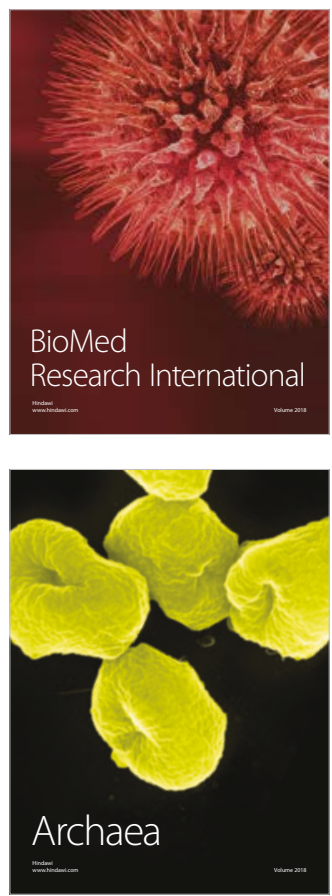